\title{
A efêmera experiência do ombudsman na imprensa campineira
}

Marcel J. CHEIDA ${ }^{1}$

\begin{abstract}
Resumo:
A rara experiência da crítica aos jornais culminou com a pioneira implantação da figura do ombudsman em meados de 1986, na Folha de S. Paulo. Outros jornais tentaram seguir o exemplo, entre eles o campineiro Diário do Povo. Por dois anos, o matutino conviveu com as análises e críticas elaboradas a partir das reclamações de poucos leitores que se aventuraram a tecer considerações sobre as notícias publicadas. Este artigo aborda a criação e a contribuição dos dois jornalistas que desempenharam a missão de colher as reclamações dos leitores e transformá-las em críticas publicadas na edição dominical do jornal ao longo de dois curtos anos. Como muitas experiências mercadológicas, a coluna do ombudsman no Diário do Povo faleceu gradualmente, ao enfrentar a antipatia da redação, do proprietário da empresa e o silêncio do leitor.
\end{abstract}

Palavras-chave: Ombudsman. Jornalismo. Jornais. Crítica à mídia, Diário do Povo.

\section{The ombudsman's ephemeral experience in the Campinas press}

\begin{abstract}
:
The unusual experience of journalism criticism has led to the breakthrough achievement of the role of the ombudsman in 1986, at the newspaper Folha de S. Paulo. Other newspapers tried to follow the lead, among them the Diário do Povo, newspaper of Campinas's city. For two years, the journal has offered analysis and critical articles elaborated from the complaints of a few readers who took a chance to comment on the news. This article discusses the creation and contribution of two journalists who have fulfilled the mission of collecting complaints from readers and transforming them into critical articles published in the Sunday edition of the newspaper over two years. As with many other experiences, the ombudsman column in Diário do Povo gradually has disappeared, facing the antipathy of the newsroom, of the owner of the journal and the silence of the reader.
\end{abstract}

Keywords: Ombudsman. Journalism. Newspaper. Midia criticismo. Diário do Povo.

\section{La efímera experiencia del defensor del pueblo en la prensa de Campinas}

\begin{abstract}
Resumen:
La rara experiencia de crítica de los periódicos culminó con la implementación pionera de la figura del ombudsman en el ano de 1986, en el periódico Folha de S. Paulo. Otros periódicos intentaron hacer lo mismo, entre ellos el periódico Diário do Povo de la ciudad de Campinas. Durante dos años, el periódico tuvo las análisis y críticas elaboradas a partir de las quejas de algunos lectores que se aventuraron a comentar las noticias publicadas. Este artículo analiza la creación y la contribución de dos periodistas que han cumplido la misión de recopilar quejas de los lectores y transformarlas en críticas publicadas en la edición dominical del periódico durante dos cortos años. Como muchas otras experiencias, la columna del ombudsman o defensor del pueblo en Diário do Povo murió gradualmente, enfrentando la antipatía de la redacción, el dueño de la compañía y el silencio del lector.
\end{abstract}

\footnotetext{
1 Jornalista formado pela Pontifícia Universidade Católica de Campinas (PUC Campinas). Professor adjunto na Faculdade de Jornalismo da PUC Campinas. E-mail: cheida@puc-campinas.edu.br
} 
Palabras clave: Ombudsman. Periodismo. Periódico. Crítica de los médios. Diário do Povo.

\section{A experiência sem legado}

Dos vários matutinos e vespertinos impressos ao longo da história de Campinas, um único jornal diário tomou a iniciativa de instituir o cargo de ombudsman em meio às mudanças ocorridas no cenário jornalístico ao final da década de 1980, com a vigência do regime constitucional, democrático.

O Diário do Povo ${ }^{2}$ comemorava, em janeiro de 1994, 82 anos. A criação da coluna do ombudsman veio em meio às inovações editoriais, quando o então senador Orestes Quércia, do Partido do Movimento Democrático Brasileiro (PMDB), comandava a Empresa Jornalística e Editora Regional, responsável pela publicação do jornal. Nesse mesmo ano, o Diário do Povo passou a ser impresso em gráfica própria, cujos equipamentos foram herdados do extinto Jornal de Hoje, um empreendimento que durou somente dois anos. O diário que durou 24 meses foi outro negócio de Orestes Quércia (ROLDÃO; CARMO-ROLDÃO, 2016), que sempre manifestou o interesse pelo jornalismo e por jornais, a ponto de construir um amplo grupo empresarial que reuniu publicações impressas (em Campinas, o Jornal de Hoje, o Diário do Povo e, em São Paulo, o Diário Popular), emissoras de rádio e televisão.

No domingo, 17 de abril daquele ano, na edição do matutino campineiro, página 13, editoria de Cidades, a manchete em seis colunas anunciava a criação do cargo de ombudsman, sob a responsabilidade do jornalista Marcos Aurélio Pereira Capitão, então com 39 anos de idade. O matutino campineiro se inspirava na experiência do confrade paulistano, a Folha de S. Paulo, que transformou a coluna do ombudsman numa referência da crítica ao jornalismo e aos jornais, como também em peça de marketing.

O Diário do Povo foi fundado por Álvaro Ribeiro em 1912 (MARIANO, 1972). Depois de sucessivas trocas de proprietários, em junho de 1960, um empresário oriundo do ramo cafeeiro, José Augusto Roxo Moreira, realiza o sonho de se envolver com um empreendimento nem tanto rentável à época: um jornal. E adquire 50\% da Empresa Jornalística Diário do Povo (ROLDÃO; CARMO-ROLDÃO, 2016).

Roxo Moreira compra, mais tarde, o restante do controle da empresa. E começa a se dedicar ao projeto de um jornal inovador. Ele pretendia tornar o Diário num dos

2 Fundado por Álvaro Ribeiro, em 1912, a primeira edição do jornal matutino circulou em 20 de janeiro daquele ano. Em 04 de novembro de 2012 saiu às ruas a última edição, 100 anos depois. Álvaro Ribeiro mesclou o jornalismo com a carreira política; foi vereador, prefeito de Campinas. Chegou a ser preso e exilado em Portugal durante o governo de Artur Bernardes, ao qual fez ostensiva oposição. (ROLDÃO; CARMO-ROLDÃO, 2016) 
jornais mais modernos do país (ROLDÃO; CARMO-ROLDÃO, 2016), o que o levou a investir na aquisição de impressoras offset, o teletipo, em 1969, e do primeiro equipamento de radiofoto instalado numa redação de um jornal na região de Campinas.

Após a morte de Roxo Moreira, num acidente de carro, em 1972, a viúva, Beatriz Roxo Moreira, o diretor Industrial, Azael Logo Filho, e o diretor Administrativo, Antonio Alarcon Garcia, renovaram o corpo de jornalistas (ROLDÃO; CARMOROLDÃO, 2016). Ao final da década de 1970, repórteres mais jovens, chefiados pelo jornalista Romeu Santini, ${ }^{3}$ respondiam pelas reportagens que levaram o matutino a ameaçar o domínio do Correio Popular. Mas, a família Roxo Moreira não conseguiu dar continuidade ao projeto. Em 1981, o então senador Orestes Quércia comprou 46\% da participação na empresa. Mais tarde, Quércia adquire o restante da participação (ROLDÃO; CARMO-ROLDÃO, 2016).

No início dos anos 1990, Orestes Quércia investe na renovação do jornal. Mesmo frente a um quadro deficitário, instala o parque gráfico na rua Sete de Setembro, na Vila Industrial, em Campinas, onde ficou até ser absorvido pela Rede Anhanguera de Comunicação (RAC), que o adquiriu em 1996, por US\$ 10 milhões (GUIMARÃES, 2010).

Entre 1990 e 1995, o Diário do Povo persegue um jornalismo mais ousado, de linha editorial mais popular. ${ }^{4}$ A contratação do jornalista João Paulo Soares, oriundo do Diário do Grande $A B C$, resultou na substituição de alguns profissionais, algo comum quando há troca de chefia numa redação.

A experiência da coluna do ombudsman no Diário do Povo registra dois mandatos, em dois anos. O primeiro, conduzido pelo jornalista de Mairinque, SP, Marcos Aurélio Pereira Capitão, de abril de 1994 ao último domingo de maio de 1995. O segundo mandato, sob a responsabilidade do jornalista gaúcho Márcio Calafiori, foi de 02 de abril de 1995 a 31 de março de 1996. Depois desses dois anos, a coluna deixou de ser publicada.

Como em muitos projetos, a trajetória da crítica em defesa do leitor foi da euforia à decepção. A expectativa inicial registrada na reportagem publicada em 17 de

\footnotetext{
${ }^{3}$ Romeu Santini chefiou a Redação do Diário do Povo na década de 1970 e começo de 1980, até as mudanças empreendidas. Bacharel em Direito pela PUC Campinas, combinou a carreira política como vereador e jornalista. Atuou também na sucursal do e $O$ Estado de $S$. Paulo, em Campinas, e dirigiu o jornalismo da Rádio Central, AM, na década de 1980. Foi o primeiro diretor de Jornalismo da EPTV Campinas, fundada em 1979 (CÂMARA..., 2018).

${ }^{4}$ Uma curiosidade, mas engajada. Álvaro Ribeiro, fundador dos dois matutinos, qualificou o Diário do Povo e o Correio Popular. O substantivo e o adjetivo denunciam a intenção em dotar Campinas de dois diários direcionados ao povo e não somente à elite.
} 
abril de 1994, com a manchete "Ombudsman vai defender interesse do leitor", numa coluna lateral, o então editor-chefe, João Paulo Soares, ${ }^{5}$ se rejubilava:

\begin{abstract}
Júnia [sic] Nogueira de Sá e Otávio Frias Filho têm razão quando dizem que a implantação da figura do Ombudsman é 'um ato de coragem"”. No caso do Diário, é também um ato de coerência.

Coerência com a linha editorial que norteou as reformas promovidas no jornal e coerência com a estratégica de líder ${ }^{6}$ adotada pelo Diário no mercado de Campinas.

O surgimento do ombudsman, tanto para os profissionais do Diário como para a direção da empresa, vem como consequência natural desse processo de mudanças, iniciado há dois anos (SOARES, 1994, p. 13).
\end{abstract}

Na mesma página, em duas colunas, um texto anotava a expectativa do diretorsuperintendente do jornal, Iberê Ribeiro de Castro: "A linha editorial do Diário privilegia o leitor de Campinas e as funções do ombudsman estarão balizadas com essa filosofia. [...] Ele (o ombudsman) terá total independência na função, sempre considerando os compromissos assumidos pelo jornal junto aos leitores".

O otimismo do diretor-superintendente, contudo, se esvaiu quando o proprietário, Orestes Quércia, decidiu encerrar a coluna, dois anos depois, numa reação que acumulava um descontentamento alimentado pelos conflitos e intrigas na redação. Márcio Calafiori ${ }^{7}$ relata o fim do trabalho como ombudsman, ocasião em que o proprietário, Orestes Quércia, lhe telefonou para proibi-lo de publicar críticas a uma das reportagens que tratava da data de fundação da Associação Atlética Ponte Preta, tradicional clube de futebol de Campinas:

Na minha antepenúltima coluna, publicada em 17 de março de 1996, dei apoio à reportagem polêmica que o Ariovaldo Izac ${ }^{8}$ escreveu sobre a data de fundação da Ponte Preta. Ele investigou o assunto por meses. Nem mesmo o historiador da Ponte Preta sabia o ano de fundação do clube, cuja ata de fundação foi rasurada. Ariovaldo Izac investigou isso a fundo. Esteve em Rio Grande (RS) e lá levantou a história do Sport Club Rio Grande, que foi fundado em 19 de julho de 1900. Ariovaldo esteve também na Biblioteca Nacional, no Rio de Janeiro. A reportagem foi apurada com dados

\footnotetext{
5 João Paulo Soares ingressou no Diário do Povo vindo do Diário do Grande ABC. Começou uma carreira e com 30 anos de idade assumiu o cargo de editor-chefe do matutino campineiro.

${ }^{6}$ O Diário do Povo tinha, como principal concorrente, o matutino Correio Popular.

7 CALAFIORI, Márcio. Depoimento concedido ao autor via e-mail, em 18 abr. 2017.

O depoimento do jornalista Márcio Calafiori foi obtido via e-mail, em 18 de abril de 2017, como parte do início dos estudos que comecei sobre o ombudsman em Campinas. Todos os outros trechos com depoimentos do jornalista foram obtidos em resposta via $e$-mail.

8 Ariovaldo Izac, jornalista esportivo, radialista, formado em jornalismo pela PUC Campinas, atuou em várias redações de Campinas e região. Em Campinas, em especial para os pontepretanos, o clube se orgulhava de ser considerado, historicamente, o mais antigo do Brasil, fundado em 1900. Após pesquisa, Izac confirmou que o clube gaúcho, Sport Club Rio Grande, havia sido fundado meses antes da Ponte Preta. A publicação do furo jornalístico abalou os pontepretanos, a ponto de o jornal e o jornalista sofrerem diversas ameaças (ZAGO, 2002).
} 


\begin{abstract}
consistentes. Como não poderia deixar de ser, o assunto incomodou. O jornal foi apedrejado, repórteres ameaçados, Ariovaldo ficou não sei quanto tempo sem poder entrar na Ponte. Portanto, nada mais sensato do que foi apoiá-lo como ombudsman. Na sexta-feira, 22 de março de 1996, estou escrevendo a minha penúltima coluna, de novo falando sobre a polêmica da Ponte Preta, pois também fui ameaçado. Nisso toca o telefone da minha mesa: 'É o ombudsman que tá falando?'. Sim, respondi. E a pessoa: 'Aqui é o Quércia. A sua coluna de domingo será de novo sobre a Ponte Preta?'. Respondi afirmativamente. E ele: 'Eu não quero que o senhor fale da Ponte.' Eu disse: 'Mas eu sou o ombudsman, posso escrever sobre o que eu quiser, tenho essa prerrogativa.' E ele: 'Eu não quero saber o que o senhor é. Eu não quero que fale da Ponte Preta no meu jornal. Não permito.' Por isso, a penúltima coluna não foi publicada (CALAFIORI, 2018, depoimento). ${ }^{9}$
\end{abstract}

As pretensões políticas e eleitorais do então ex-governador Orestes Quércia ${ }^{10}$ miravam o controle de veículos de comunicação, entre eles os jornais impressos, na tentativa de melhorar a popularidade em favor de sua candidatura. Em 1992, Quércia desencadeia a renovação administrativa e editorial do Diário do Povo, em cuja empresa detinha o controle acionário.

No segundo semestre de 1992, o jornal recebeu um novo grupo de jornalistas, entre eles João Paulo Soares, então com 28 anos de idade, que iria assumir o cargo de editor-chefe. Quércia havia consultado vários jornalistas, entre eles Alexandre Polesi, do Diário do Grande $A B C$, que indicou colegas para compor a equipe em Campinas.

De acordo com João Paulo Soares (SOARES, 2018, depoimento) ${ }^{11}$, a reforma do jornal compreendia um esforço resultante de duas principais variáveis: a busca de maior credibilidade do ex-governador na terra na qual ancorou a carreira política e a concorrência com o principal jornal da cidade, o Correio Popular. Ao mesmo tempo, superar o vício de anos anteriores nos quais o jornal enfrentou uma fase na qual perdeu a qualidade editorial encontrada na década de 1979 e início de 1980.

9 CALAFIORI, Márcio. Depoimento concedido ao autor via e-mail, em 22 jun. 2018.

10 Orestes Quércia começou a carreira política em Campinas, como vereador pelo Partido Liberal. Com o golpe de 1964, ingressou no Movimento Democrático Brasileiro (MDB). Foi eleito deputado estadual e, depois, prefeito do município. Após deixar a Prefeitura de Campinas, foi eleito senador por são Paulo. Foi vice-governador na chapa do governador Franco Montoro e, na sucessão, eleito governador para o mandato de 1987 a 1991. Em 1994, pelo PMDB, disputou a eleição para presidente da República. Naquele ano, Fernando Henrique Cardoso, do Partido da Social Democracia Brasileira (PSDB), foi eleito. Desde então, Quércia investiu na vida empresarial, até falecer vítima de um câncer em dezembro de 2010 (GOUGET; ALDÉ; SETEMY, s.d.).

11 João Paulo Soares encaminhou, após pedido, um depoimento no qual relata as lembranças que ainda guarda da época. Todas os trechos nos quais constam a fala dele foram obtidos nesse relato, com exceção do registro das notas taquigráficas da Câmara Municipal de Campinas. João Paulo Soares é formado em Jornalismo pela Universidade Católica de Santos. Entre 1988 e 2004, trabalhou em diversos jornais, entre eles a Folha de S. Paulo (regional Sudeste) e o Diário Popular (Revista JÁ).

SOARES, João Paulo. Depoimento concedido ao autor via e-mail, em 11 jul. 2018. 
Quércia costurava a candidatura à Presidência da República. Mais um motivo para contornar a linha editorial, de modo a evitar fagulhas com o proprietário, conforme explicou Soares (2017): “Claro que em relação ao próprio Quércia havia limites. Não dávamos manchetes contra ele nem ficávamos investigando sua vida, mas publicávamos as matérias negativas que vinham das agências, cuidando para separar fatos de boatos, dados de suposições, acusações formais de denúncias anônimas etc."

A ideia sobre a implantação da coluna do ombudsman era mais uma entre outras para enfrentar o concorrente e angariar mais leitores e, portanto, faturamento. As mudanças introduzidas desde então elevaram as vendas, a circulação e a receita do jornal. Soares relembra:

Três anos depois (do início da reforma), o Diário saiu de um targed de $18 \%$ para $43 \%$ do mercado de Campinas, e avançava para tomar a liderança do Correio, o que tornou a disputa entre as duas redações cada dia mais encarniçada.

A criação do ombudsman é parte dessa disputa, uma ação que hoje considero precipitada [...]. Porém, no quesito prestígio e credibilidade, achávamos que era uma grande tacada (SOARES, 2018, depoimento).

A declaração de João Paulo Soares revela uma tortuosa caminhada da Direção até a inauguração da primeira coluna, pois a desconfiança deu lugar à relativa convicção do valor mercadológico do ombudsman que, para o diretor-superintendente, Iberê Ribeiro de Castro, serviria para reafirmar o compromisso com os leitores. A oposição entre as intenções mercadológicas e a reação pragmática da empresa se encaixa no conflito ou na contradição entre o discurso e a prática da crítica ao jornal (sobre tais conflitos nas empresas jornalísticas, ver KARAM, 2004, p. 117).

Depois de 25 anos da criação da coluna, João Paulo Soares avalia, porém, que o projeto era desnecessário e que a Redação não estava preparada para desenvolvê-lo:

Outra questão, igualmente relevante, é que nós não precisávamos de um ombudsman, não tinha a menor necessidade, e, portanto, teve pouca serventia. Não agregou prestígio; não tinha nada a ver com nosso leitor, que nunca soube do que se tratava aquela coluna; e não se encaixou na rotina de produção da Redação, regulada pela cooperação, pela responsabilidade solidária e por regras flexíveis, com espaço para o erro, não por sistemas rígidos de metas e cobranças (SOARES, 2018, depoimento).

O desalento de João Paulo Soares parece desabar no ceticismo em torno da profissão e do papel do ombudsman. As graves barreiras postas em torno do jornalismo e dos jornais nesses últimos 25 anos são objetos de vários estudos. Ramonet (2013, p. 
53) observa que "na maioria das democracias é que há um conflito entre a sociedade e os meios de comunicação. Tal conflito não é novo, pelo contrário, vem se agravando há uns dez ou quinze anos. Aprofunda-se na sociedade a crítica contra o modo de atuação da mídia dominante".

A tentativa de utilizar o ombudsman em duas finalidades, mercadológica e ética, quando a internet iniciava naquela década a expansiva popularização, pareceu naufragar, conforme desabafa Soares:

\begin{abstract}
Ocorre, como é sabido, que a rotina das redações produz profissionais sobrecarregados de pautas e tarefas, esgotados física e psicologicamente pelas múltiplas cobranças vindas de todos os lados, lutando enlouquecidamente contra o tempo, tendo de se adequar às imposições editoriais e aos interesses político-empresariais das empresas nas quais trabalham, o tempo todo submetido a ordens e contraordens muitas vezes contraditórias e esquizofrênicas, e ainda subjugados pelo império das idiossincrasias dos chefetes de plantão, que sempre os há, e pelo fantasma do desemprego, que ronda permanentemente.

$[\ldots]$

No caso da nossa experiência, repito, minha avaliação hoje é que não precisávamos de nenhuma das duas coisas. Nem nós nem nossos leitores, que estavam muito bem servidos de jornalismo da melhor qualidade nas páginas do Diário do Povo de então (SOARES, 2018, depoimento).
\end{abstract}

A percepção de João Paulo Soares é impregnada de um ceticismo sobre a autocrítica institucional apontada para a figura do ombudsman. A ela se agrega o descrédito que gradualmente tomou conta da relação entre o público e os jornais, num ambiente de acirrada competição econômica e cultural, além das relações políticas.

\title{
A euforia
}

A eufórica esperança de mudanças nesse início de projeto, contudo, estava estampada na edição do dia 17 de abril, num texto no qual o jornal anunciava a novidade - que logo encontrou caminhos desviantes. Capitão (17 abr. 1994, p. A3) afirmava a crença de que o "ombudsman é a última palavra na busca da qualidade e da manutenção dos compromissos assumidos por um jornal junto à comunidade".

Ao ouvir e registrar as manifestações dos leitores, Capitão (17 abr. 1994, p. A3) teria o compromisso "com carta branca, para julgar, criticar e comentar, inclusive comparando enfoques e angulação de matéria com outros jornais". Esses trechos inauguraram a publicidade das intenções do jornal para com a sociedade e com os leitores. A proposta da "carta branca", expressão que afirma a autonomia plena do ombudsman na elaboração da crítica ao jornal, é confirmada por Mendes (1998, 
Introdução, s/n): "Uma característica bem particular das colunas de ombudsman é que são um espaço para a crítica de tudo o que é publicado no jornal. O discurso do ombudsman aparece em uma situação privilegiada com relação aos demais discursos presentes no jornal".

A convicção de ombudsman em torno do cargo seria reafirmada na primeira coluna publicada na edição do dia 18, na página 06, editoria de Opinião. Educadamente, Capitão informava o leitor que havia deixado o cargo de editor de Política Nacional para ingressar no projeto inovador. Ele anunciava:

A partir de hoje deixo de responder pela editoria de Política Nacional do Diário do Povo, cargo que ocupei por cerca de um ano e meio, para ser o primeiro ombudsman da história desse jornal. Afasto-me das fontes noticiosas e do convívio direto com os colegas de redação, ainda que temporariamente, para integrar um projeto editorial que objetiva um amplo canal de ligação entre o leitor e esse órgão de comunicação (CAPITÃO, 18 abr. 1994, p. 06).

Exultante também foi o tom do editorial publicado no mesmo dia:

Hoje é um dia histórico para a imprensa do Interior paulista. Ao tomar a iniciativa de nomear um ombudsman para um jornal de porte médio, longe da Capital, o Diário assume não só o papel pioneiro, mas também de criador de uma tendência que transcende os limites da guerra particular de mercado travada pela imprensa campineira (EDITORIAL, 18 abr. 1994, p. 06).

Ainda na edição do dia 19 de abril, um texto em duas colunas, na página 03, informava que o leitor do jornal assimilava "bem" o trabalho do ombudsman. A precocidade da coluna não intimidava o otimismo do autoelogio:

O primeiro dia de trabalho do jornalista Marco Aurélio Capitão, como ombudsman do Diário, demonstrou que o leitor e os profissionais que trabalham na Redação assimilaram bem a ideia. Capitão assumiu o cargo ontem, com a tarefa de defender os interesses dos leitores e passar adiante suas queixas, observações e sugestões com relação que [sic] é publicado no jornal. Capitão avalia que as pessoas entenderam rapidamente a função de aliado que o ombudsman representa. Ontem, ele recebeu mais de 20 telefonemas, além de telegramas. A maioria dos telefonemas era de leitores, embora tenha recebido também congratulações de jornalistas de outros veículos, políticos e empresários (LEITOR..., 19 abr. 1994, p. 03).

No mesmo texto, buscava a cumplicidade dos colegas de Redação, os quais, segundo teria percebido Capitão, se empenhavam em "melhorar o tratamento dado às notícias".

A primeira coluna publicada com as reclamações, queixas e críticas é datada de domingo, 24 de abril daquele ano. Diagramada em quatro colunas por 39 centímetros, 
na página 02, a coluna encimada pela vinheta Coluna do Ombudsman tinha por título Missão Possível. Era um trocadilho com o antigo seriado e depois filme Missão impossível. Nela, Capitão focava o tratamento dos jornais em relação às candidaturas na disputa pela Presidência da República. E, é claro, o objetivo era expor a relação entre o candidato do PMDB, Orestes Quércia, o jornal Diário do Povo e o desempenho do ombudsman.

$\mathrm{Na}$ coluna inaugural, Capitão redigiu e editou nove comentários. O espaço foi diagramado com duas colunas internas, uma intitulada Pré-Pauta e a outra, Preto no Branco. Na primeira, anotava assuntos que teriam desdobramentos ao longo da semana vindoura. $\mathrm{Na}$ segunda, reunia seis pequenos comentários, como o de abertura: "Desinformação - O campineiro que fica na cidade nos feriados prolongados continua à margem da informação. Tanto o Diário como o Correio [Correio Popular, o jornal concorrente direto] optam por dar folga a toda sua equipe nos feriados, como aconteceu na última quinta-feira, deixando o leitor na mão.”

O comentário em destaque, contudo, encontrava-se na coluna interna Pré-Pauta. Ali, Capitão começou a pôr o dedo na ferida. E anotava a participação do proprietário, Orestes Quércia, como autor de artigos publicados em colunas do jornal, no primeiro caderno, de política nacional. Aqui, a íntegra:

Neste domingo, pela segunda semana consecutiva, o ex-governador Orestes Quércia volta a utilizar a página 4 do Diário para publicar seus artigos. Nada haveria de anormal nesse procedimento não estivesse Quércia buscando legenda para candidatar-se a presidente da República. No domingo passado, seu artigo 'Rumo à prosperidade' foi para a coluna Conjuntura, ocupada durante a semana pelo jornalista Carlos Chagas. Desta vez, o artigo 'O futuro é agora’ sai na coluna Linhas Gerais (CAPITÃO, 24 abr. 1994, p. 2).

Em resposta, na coluna da semana seguinte, $1^{\circ}$ de maio, o editor-chefe, João Paulo Soares, enviou uma mensagem a Capitão, na qual explicava a presença de Orestes Quércia como articulista do jornal:

O ex-governador escreve há muito tempo no Diário, independente de sua condição atual de pré-candidato, e, nesse sentido, é encarado [sic] como articulista fixo, da mesma forma como José Sarney, outro pré-candidato, tem espaço garantido às sextas-feiras na Folha de S. Paulo. De qualquer maneira, a sugestão é interessante e será estudada dentro de nossas limitações de espaço (SOARES, $1^{\circ}$. maio 1994, p. 02). 
Marcos Aurélio Capitão ${ }^{12}$ afirma que o proprietário Orestes Quércia não interveio para censurar ou vetar comentários da coluna enquanto exerceu o cargo. Mas, a imagem do político em Campinas era um fator que inibia a comunidade de leitores do jornal: "O jornal, por ser de propriedade de um político bastante conhecido e polêmico na cidade (Orestes Quércia), não era visto como exemplo de seriedade ou afeito a ações de transparência e objetividade" (CAPITÃO, 2018, depoimento). Porém, essa imagem ou a relação do político com a sociedade campineira não fora o principal obstáculo à rotina de trabalho do primeiro ombudsman.

As primeiras pedras postas no caminho do ombudsman vieram de baixo. Da Redação, onde os colegas gradualmente começaram a expor o descontentamento com as críticas:

Enfrentei muitas críticas da empresa e dos colegas, pois além da coluna semanal eu encaminhava um relatório diário a cada jornalista. Alguns colegas chegavam a ir até minha sala para tirar satisfação, o que fez com que eu mudasse de sala em outra repartição, fora da redação. A maior animosidade, todavia, acontecia com a chefia da redação (CAPITÃO, 2018, depoimento).

Na edição do dia 5 de junho, na página 02, Capitão leu, surpreso, o texto, em duas colunas por $32 \mathrm{~cm}$., no alto da página, de que trata no depoimento acima. Sob um chapéu "A verdade dos fatos", o título era uma réplica do secretário de Redação, Márcio Calafiori, que coincidentemente veio a sucedê-lo no cargo: "Análise equivocada de um erro involuntário". Calafiori assinava logo abaixo.

Na publicação, o secretário de Redação ressaltava, logo na abertura, que o ombudsman "foi infeliz na crítica que abre a sua coluna de hoje (ao lado): Exemplo de antijornalismo. Ao contrário do que afirma, o Diário não se 'achou no direito de julgar e condenar os padres salesianos Orivaldo Votolin e Sergio Baruffi', acusados de responsabilidade na questão da demolição do Externato São João" (CALAFIORI, 05 jun. 1994, p. 02).

Calafiori apontava a ausência das respostas dadas pela Redação às críticas publicadas na coluna dominical do ombudsman: "Acho que o ombudsman erra, por exemplo, quando critica publicamente o Diário e, posteriormente, deixa de publicar as nossas respostas. Este sim é um autêntico exemplo de antijornalismo" (CALAFIORI, 05 jun. 1994, p. 02). Calafiori usava o mesmo termo empregado por Capitão no título da coluna daquele dia: "Exemplo de antijornalismo", cuja crítica destacava a inserção de

12 CAPITÃO, Marcos Aurélio Pereira. Depoimento ao autor via e-mail, em 21 maio 2018. 
uma frase ao final da reportagem de autoria da jornalista Soraya Agége, sem seu consentimento. A reportagem tratava a demolição de uma das alas do antigo prédio que abrigava o tradicional Externato São João. Capitão relatava, na coluna, o interesse do Ministério Público em abrir um inquérito para apurar se houvera infrações à lei de proteção ao meio ambiente. Como a repórter informava que não encontrara os padres responsáveis pela demolição, o editor (não há citação do nome do editor responsável) inseriu, ao final do texto da repórter, a seguinte afirmação: “A dupla está foragida".

No texto resposta, Calafiori (05 jun. 1994, p. 02) admitia que o jornal tratava os dois padres responsáveis pela demolição como "foragidos". Mas que, "lamentavelmente, por um erro de interpretação, a editoria de Cidades se referiu aos padres usando a expressão foragidos" [grifo do redator]. O termo remetia à condição de padres fugitivos da Justiça.

A reparação sobre a condição dos padres veio numa errata publicada pelo jornal na quarta-feira, $1^{\circ}$ de junho, um dia depois da edição na qual se encontrava a reportagem classificada pelo ombudsman de "sensacionalista".

A polêmica não parou aí. Em carta publicada na coluna Espaço do Leitor, página 04, na edição do dia oito, o padre e jornalista Luis Carlos F. Magalhães, que chegou a responder pela Comunicação da Arquidiocese de Campinas, ressaltava a manchete "sensacionalista" do jornal quando publicou a reportagem sobre o caso da demolição da ala do Externato São João.

\section{O execrado desde a origem}

Os conflitos entre ombudsman e redação são temas de análises e avaliações sobre o papel da crítica ao jornal desde que Alberto Dines ${ }^{13}$ criou os Cadernos de Jornalismo, projeto pioneiro na crítica comparada dos jornais elaborado no Jornal do Brasil, na década de 1960. No posfácio da $9^{a}$ edição da obra $O$ papel do jornal e a profissão de jornalista, Dines relata o episódio ocorrido com o publisher da Folha de S. Paulo, Octávio Frias Filho, quando disse a ele que iria criar uma coluna, o Jornal dos Jornais, publicadas aos domingos, de 1975 a 1977. "Você só vai arranjar inimigos", advertiu Frias a um Dines persistente (DINES, 2009, p. 19).

Mais tarde, em carta ao então recém-nomeado ombudsman da Folha de S. Paulo (COSTA, 2006), em outubro de 1989, Alberto Dines cumprimentava o jornal pelo

13 A revista Pesquisa Fapesp publicou, na edição de abril de 2012, uma longa entrevista concedida por Alberto Dines, na qual lembrava que o lançamento dos Cadernos de Jornalismo perturbou colegas na redação do Jornal do Brasil (DINES, 2012). 
projeto. Mas, alertava o jornalista Caio Túlio Costa sobre as armadilhas em torno do cargo, em especial quanto ao sentimento de potência e de salvador do mundo jornalístico na alma de quem assumia a missão. Dizia Dines a Caio Túlio: "Não cometa o erro de deixar-se envolver pela ira sagrada ou pela missão salvacionista. Isto custoume uma dúzia de ferrenhos inimigos sem que eu tivesse conseguido quebrar o bezerro de ouro" (COSTA, 2006, p. 94).

Possivelmente, Marcos Aurélio Capitão tenha constatado que os ideais salvacionistas no início do trabalho tenham, gradualmente, se perdido pelo esforço dos colegas em minimizarem ou desprestigiarem as críticas, bem como pela queda da repercussão dos comentários.

Percebo que se, naquela época, já era difícil dar certo a figura do Ombudsman, hoje é muito mais complicado. Dá certo na Folha porque a própria Folha cuidou de reduzir a coluna numa seção mocozada que ninguém lê e por que o próprio jornal escolhe a dedo os ditos "representantes dos leitores". Repare que ninguém mais comenta essa coluna, eu mesmo não sei quem é o atual (CAPITÃO, 2018, depoimento).

Capitão parece ter caminhado em trajeto semelhante ao de Caio Túlio Costa, que assim respondeu à advertência de Dines: "pois eu - se consegui deixar de lado a missão salvacionista - também não consegui quebrar o bezerro de ouro. Nem os jornalistas conseguiram me esquecer como sugeriu Dines" (COSTA, 2006, p. 19).

Contudo, o desencanto de Marcos Aurélio Capitão não se restringiu ao comportamento reativo dos colegas. Os leitores também foram uma decepção para ele. O apoio e a manifestação esperada ficaram na fase inicial, da expectativa em torno dos possíveis efeitos da coluna. Enquanto os colegas reagiram logo nas primeiras edições da coluna, os leitores demorariam ou quase não perceberiam a relevância da coluna:

Demorou para o leitor entender o papel que o ombudsman exercia no jornal. A maioria via com desconfiança, quero dizer, entendia que tudo aquilo era combinado com a direção do jornal. Com os colegas isso não aconteceu, pois as brigas com a chefia e com a direção do jornal logo chegaram ao conhecimento de todos que perceberam que eu não aceitava ingerências (CAPITÃO, 2018, depoimento).

Mesmo assim, o sucessor de Capitão no cargo, Márcio Calafiori, testemunhou a autonomia do colega no cargo naquele primeiro ano do projeto. Ou seja, mesmo com os conflitos com os colegas e o estranhamento da direção da empresa, o trabalho foi desenvolvido com base na independência profissional: 
O Capitão foi um ombudsman duro. Essa primeira experiência do ombudsman no Diário foi tensa, inclusive porque, como já salientei aqui, não foi algo pensado e elaborado. [...] Como secretário de redação, eu botava panos quentes, conversava com o Capitão, tentava esclarecer e amenizar, mas ele se mantinha fiel ao que pensava. A abordagem do ombudsman fazia com que a direção do jornal ficasse tensa e temesse pelo futuro do novo projeto do Diário do Povo. O certo é que o Capitão exerceu o cargo com independência (CALAFIORI, 2018, depoimento).

Capitão ficou no cargo o tempo previsto originalmente: um ano. E com independência, conforme seu relato e o do jornalista Márcio Calafiori. Mas, depois de vinte e quatro meses, a coluna desapareceu. A intervenção administrativa, o descontentamento do proprietário Orestes Quércia e todo o saldo de insatisfação e até apatia da Redação contribuíram para a coluna alcançar o oblívio.

\section{$\mathrm{O}$ ano que terminou}

Pouco mais de oito meses depois que Márcio Calafiori deixava o cargo de ombudsman, como sucessor de Marcos Aurélio Capitão, o Diário do Povo foi adquirido pelo concorrente direto, a empresa que publicava o Correio Popular. Uma compra anunciada no valor de US\$ 10 milhões, cujo pagamento em parcelas contribuiu para o Correio Popular se descapitalizar nos anos seguintes. Seis anos depois, em novembro de 2012 o Diário do Povo parou de circular (ROLDÃO; CARMO-ROLDÃO, 2016). Incorporado pela empresa que editava o Correio Popular, a Rede Anhanguera de Comunicação (RAC), o fim melancólico do matutino que inovou no jornalismo campineiro ainda era editado por 10 jornalistas. Todos foram demitidos, então.

Calafiori era o secretário de Redação e foi quem tomou a primeira iniciativa em contradizer o ombudsman Capitão logo no começo do projeto de crítica ao jornal. Convidado pelo diretor superintendente da empresa, Iberê Ribeiro de Castro, sob a justificativa de que seria alguém de confiança para assumir o cargo em substituição ao antecessor, o então secretário de Redação pensou, refletiu, até resistiu, mas aceitou o convite. A decisão era a de assumir a responsabilidade num cenário de concorrência acirrada com o Correio Popular, numa iniciativa que integrava, segundo ele, os planos de marketing para melhorar o posicionamento comercial do Diário do Povo.

Márcio Calafiori trazia a parcimônia do cargo de secretário de Redação, quando tentou colocar amortecedores no conflito entre o ombudsman e os colegas. Nas primeiras semanas, o segundo ombudsman do Diário do Povo detectou comportamentos já apontados pelo antecessor, Marcos Aurélio Capitão. O atrito entre colegas da 
Redação e ele foi se esvaindo, se desfazendo:

\begin{abstract}
Mas sinceramente falando, depois que se acostumou com o ombudsman pouca gente na redação do Diário se importava com a coluna. Às vezes, alguém elogiava ou criticava, mas não passava disso. E muito menos o leitor. Pelo menos o leitor do Diário não dava a mínima. Dificilmente fui acionado por carta ou por telefone. Na minha última coluna, em 31 de março de 1996, escrevi isso: "A função de ombudsman só é popular entre os colegas jornalistas. Não sei se está fadada ao sucesso aqui no Brasil." O tempo provou que eu tinha razão. Quero ressaltar que além da coluna de ombudsman, que era publicada aos domingos, eu fazia a crítica interna do jornal, todos os dias, de segunda a sexta-feira. Essa crítica era muito lida e comentada na redação. Chamava-se: A Patada (CALAFIORI, 2018, depoimento).
\end{abstract}

A coluna do ombudsman fez o jornalista ponderar sobre o papel crítico que deveria desempenhar, após responder pela secretaria de Redação durante um ano. Agora, convidado para assumir o "espinhoso encargo", nas palavras de Alberto Dines, Calafiori relembra, com honestidade, a postura que adotou ao receber o convite do diretor superintendente, Iberê Ribeiro de Castro. Segundo Calafiori, mesmo ao tentar "pular fora" do convite, o aceitou. E adotou a tática "da maioria dos ombudsmen, "mordia e assoprava".

O convite a Calafiori, secretário de Redação, evidenciou o conflito de interesses entre a empresa e o direito do leitor. No meio, o ombudsman. Bucci (2000) teceu longa análise sobre o conflito de interesses da empresa e do jornalismo. Aquela, pragmática, preocupada com a sobrevivência administrativa e econômica; este, missionário, preocupado com o interesse público centrado no direito do cidadão. A relação entre o "Estado" e a "Igreja", conforme a metáfora adotada pelos jornais norte-americanos, ficava evidente à medida que os conflitos foram evidenciados para Calafiori.

O perfil mercurial das relações comerciais sempre afetou os interesses empresariais. Não foi diferente com Orestes Quércia e Márcio Calafiori. Ao tocar no modo como a empresa era gerenciada, o ombudsman não se acovardara e investira na crítica sobre uma área a qual poucos jornalistas dominam: a administração e as estratégias comerciais:

Uma vez recebi um recado do Orestes Quércia dizendo que depois ele iria conversar comigo bem de pertinho. Foi por causa da coluna intitulada: "A reestruturação do Diário", publicada em 29 de outubro de 1995. É uma longa história, mas resumindo: depois que sem mais nem menos o Quércia decidiu pôr abaixo o processo de reestruturação do Diário do Povo, decisão que veio da noite para o dia, sem mais delongas, o jornal perdeu todos os investimentos que vinham sendo feitos nos últimos seis anos. Essa decisão do Quércia funcionou como uma bomba na redação, pois tudo no Diário 


\begin{abstract}
começou a ser desmantelado, inclusive o sistema de entrega do jornal para os assinantes, além do enxugamento da redação [...]. Foi a coluna mais difícil que escrevi, pois era uma crítica direta ao dono do jornal. Preocupados com o desmantelamento do jornal, os colegas me diziam: "Quero ver o que você vai escrever na coluna, quero ver se você é ombudsman mesmo ou se não passa de um vendido." Os nervos de todos no Diário estavam à flor da pele. Quando a coluna foi publicada, achei que tinha cumprido o meu papel. O Quércia me ameaçou, mas não fez nada (CALAFIORI, 2018, depoimento).
\end{abstract}

A venda do Diário do Povo para a Rede Anhanguera de Comunicação (RAC) o integrou a um novo modelo de negócio, mais amplo, que buscou congregar as várias modalidades de produtos, tanto o impresso como o digital. Bucci (2000) pondera sobre essas radicais mudanças que põem o jornalismo tradicional de ponta cabeça. Ou seja, o Diário do Povo deixou de ser o matutino, com pretensões de independência sustentada pelo faturamento no tripé assinaturas, venda em bancas e anúncios (aí, incluídos os classificados) para compor um dos itens da RAC, que se modernizava com os recursos digitais (ANDRETTA, 2016).

Da euforia à depressão e ao esquecimento, a figura do ombudsman num jornal de Campinas não enraizou e muito menos frutificou. Mesmo o jornal Correio Popular esboçou, naquele período, a criação de um conselho de leitores, ${ }^{14}$ mas sem sucesso. $\mathrm{O}$ boato de que iria instituir a coluna do ombudsman contribuiu para o Dário do Povo se antecipar ao concorrente mesmo aos trancos, sem uma preparação ancorada num amplo e discutido projeto editorial. $\mathrm{O}$ imediatismo comercial na ânsia de ganhar audiência, muito comum, levou o jornal a criar, pragmaticamente, a coluna.

Capitão e Calafiori evidenciam como o espinhoso trabalho rende muito mais peso a quem o desempenhou. A responsabilidade do ombudsman se defronta com pelo menos três adversários poderosos: a direção da empresa, os colegas de redação e a comunidade de leitores. Em Campinas, ambos caminharam por pedregoso trajeto no qual a iniciativa que nascia num contexto de competição comercial definhou pela falta de oxigenação destinada à sobrevivência da empresa jornalística. Era o anúncio do processo de morte do jornal impresso Diário do Povo.

\footnotetext{
${ }^{14}$ Quase 17 meses depois da publicação da última coluna do ombudsman no Diário do Povo, na edição de 21 de agosto de 1997, o Correio Popular anunciava o início das atividades do Conselho de Leitores, formado por cidadãos para comentar e apresentar demandas em torno do noticiário do jornal. O primeiro parágrafo da notícia sobre o começo do trabalho do Conselho, assim pontificava: "Integrar o leitor ao processo de confecção do jornal. Com esse objetivo, o Correio Popular inicia hoje o projeto 'Conselho de Leitores'. Cada editoria formará um grupo de consultores, composto por representantes de diversos setores da sociedade, que expressará suas opiniões, críticas e sugestões sobre o produto que chega às bancas e à casa dos assinantes todos os dias" (CORREIO... 21 ago.1997, p. 03).
} 
Referências

ANDRETTA, Cyntia B. Correio Popular: o cenário a partir da criação da RAC. In: ROLDÃO, Carlos Gilberto, ORMANEZE, Fabiano; CARMO-ROLDÃO, Ivete (org.). A imprensa em Campinas - retratos da história. Holambra, São Paulo: Editora Setembro, 2016. p. 131-149.

BUCCI, Eugênio. Sobre Ética e Imprensa. São Paulo: Companhia das Letras, 2000.

CALAFIORI, Márcio. Análise equivocada de um erro involuntário. Diário do Povo, Campinas, São Paulo, p. 02, 05 jun. 1994.

CÂMARA em luto: Campinas perde Romeu Santini, vereador por seis vezes e presidente do Legislativo por sete; velório ocorrerá no Plenário da Casa. Câmara Municipal de Campinas, Campinas, São Paulo, 21 nov. 2018. Disponível em: http://www.campinas.sp.leg.br/comunicacao/noticias/2018/novembro/camara-em-lutocampinas-perde-romeu-santini-vereador-por-seis-vezes-e-presidente-do-legislativo-porsete-velorio-ocorrera-no-plenario-da-casa. Acesso em: 01 de julho de 2020.

CAPITÃO, Marcos Aurélio Pereira. Ombudsman: um juiz, duas sentenças. Diário do Povo, Campinas, São Paulo, p. 02, 1º. maio 1994.

CAPITÃO, Marcos Aurélio Pereira. Ombudsman vai defender interesses do leitor. Diário do Povo, Campinas, São Paulo, p. A3, 17 abr. 1994.

CAPITÃO, Marcos Aurélio Pereira. Opinião. Diário do Povo, Campinas, São Paulo, p. 06, 18 abr. 1994.

CAPITÃo, Marcos Aurélio Pereira. Missão possível, Diário do Povo, Campinas, São Paulo, p. 2, 24 abr. 1994.

CASTRO, Iberê Ribeiro. Ideia reforça projeto editorial. Diário do Povo, Campinas, São Paulo, p. A3, 17 abr. 1994.

COSTA, Caio Túlio. Ombudsman - o relógio de Pascal. São Paulo: Geração Editorial, 2006.

CORREIO implanta hoje Conselho de Leitores. Correio Popular, Campinas, São Paulo, 21 ago. 1997, caderno de Economia, p. 03.

DINES, Alberto. O papel do jornal e a profissão de jornalista. 9. ed. São Paulo: Summus Editorial, 2009.

EDITORIAL, Diário do Povo, Campinas, São Paulo, p. 06, 18 abr. 1994.

GUIMARÃES, Bruna V. Rede Regional de Comunicação: uma tendência no interior paulista. In: CONGRESSO BRASILEIRO DE CIÊNCIAS DA COMUNICAÇÃO, 29., 2006, Brasília. Anais Eletrônicos [...], São Paulo: Intercom, 2006. Disponível em: http://www.intercom.org.br/papers/nacionais/2006/resumos/R1477-2.pdf. Acesso em: 03 jul. 2020. 
GOUGET, Gisele; ALDÉ, Lorenzo; SETEMY, Adrianna. Orestes Quércia. Centro de Pesquisa e Documentação de História Contemporânea do Brasil (CPDOC), Fundação Getulio Vargas, c2010. Disponível em: http://www.fgv.br/cpdoc/acervo/dicionarios/verbete-biografico/orestes-quercia. Acesso em: 30 jun. 2020.

KARAM, Francisco J. A ética jornalística e o interesse público. São Paulo: Summus Editorial, 2004.

LEITOR do Diário, Diário do Povo, Campinas, São Paulo, p. 03, 19 abr. 1994.

MARIANO, Julio. História da Imprensa em Campinas. Campinas: edição do autor, [ s. n.], 1972.

MENDES, Jairo Faria. O ombudsman e o público, parte 1. Observatório da Imprensa, edição 54, 05 out. 1998. [Publicação em três partes de dissertação do autor defendida na Universidade Federal do Rio de Janeiro, em 1998]. Disponível em: http://observatoriodaimprensa.com.br/primeiras-edicoes/o-ombudsman-e-o-pblicoparte1/. Acesso em: 17 maio 2018.

MOURA, Mariluce; LINS DA SILVA, Carlos Eduardo. Alberto Dines: lições de jornalismo. Revista Pesquisa Fapesp. São Paulo, ed. 194, abril 2012. [Entrevista]. Disponível em: http://revistapesquisa.fapesp.br/2012/04/10/alberto-dines-licoes-dejornalismo/. Acesso em: 27 jun. 2018.

RAMONET, Ignacio. Meios de Comunicação: um poder a serviço de interesses privados. In: MORAES, Dênis de; RAMONET, Ignacio; SERRANO, Pascual (org.). Mídia, Poder e Contrapoder - da concentração monopólica à democratização da informação. São Paulo: Boitembo; Rio de Janeiro: Faperj, 2013. p. 53-70.

ROLDÃO, Carlos Gilberto; CARMO-ROLDÃO, Ivete. Diário do Povo, uma história centenária. In: ROLDÃO, Carlos Gilberto; ORMANEZE, Fabiano; CARMOROLDÃO, Ivete (org.) A imprensa em Campinas - retratos da história. Holambra, SP: Editora Setembro, 2016. p. 15-44.

ROLDÃO, Carlos Gilberto, ORMANEZE, Fabiano; CARMO-ROLDÃO, Ivete (org.). A imprensa em Campinas - retratos da história. Holambra, São Paulo: Editora Setembro, 2016.

SOARES, João Paulo. Ombudsman vai defender interesse do leitor. Diário do Povo, Campinas, São Paulo, p. 02, 17 abr. 1994.

ZAGO, Vitorio Luis Oliveira. Futebol em Campinas: a história e evolução do dérbi campineiros. 2002. Dissertação (Mestrado em Multimeios) - Departamento de Multimeios, Universidade de Campinas, Campinas, São Paulo, 2002.

Submetido em: 31.10.2019

Aprovado em: 21.01.2020 